\title{
Pengembangan Ekonomi Lokal Melalui Olahan Buah Nanas Di Desa Bedali Kecamatan Ngancar Kabupaten Kediri
}

\author{
Indah Yuni Astuti ${ }^{1}$, Muhammad Alfa Niam² ${ }^{2}$ dan Tri Handayani ${ }^{3}$ \\ ${ }^{1,2,3}$ Universitas Islam Kadiri \\ Email : ${ }^{1}$ indahyuni@uniska-kediri.ac.id, ${ }^{2}$ alfa_niam69@yahoo.com, ${ }^{3}$ handayanitree@ gmail.com
}

\begin{abstract}
The potential of Bedali village in the aspect of agriculture, especially pineapple fruit becomes its own potential. The majority of Bedali village community work Ngancar subdistrict as farmers who produce soursop fruit and pineapple. The abundance of pineapple in Bedali village is one of the reasons for devotion to this society. One of the processed products produced by $P K K$ mothers in Bedali Village is pineapple juice. The problem faced by pineapple farmers in Bedali village is the limitation of tools owned and lack of knowledge and skills in the processing of pineapple fruit. Another problem is that when the number of pineapple fruit is abundant, while the market demand is low, then the pineapple fruit will not sell, the result of pineapple fruit becomes rotten and when it is rotten it will be discarded. This will cause harm to farmers. So, PKK mothers who also become farmers of pineapple fruit should get attention to change mindset not only able to farming, but also able to cultivate agricultural products. The methods implemented in this community service activities are to provide coaching and training of aspects of production and business management aspects. From the community service program, it is the delivery of pineapple fruit processing training to jam and cakes. Bookkeeping and financial management training to PKK mothers and the provision of machine tools to support the production of processed pineapple juice.
\end{abstract}

Keywords: Product, agricultural produce, processing.

\begin{abstract}
Abstrak
Potensi Desa Bedali dalam aspek pertanian khususnya buah nanas menjadi potensi tersendiri. Mayoritas pekerjaan masyarakat desa Bedali Kecamatan Ngancar sebagai petani yang menghasilkan buah sirsak dan nanas. Melimpahnya buah nanas di desa Bedali menjadi salah satu alasan tujuan pengabdian kepada masyarakat ini. Salah satu produk olahan yang dihasilkan oleh ibu-ibu PKK di desa Bedali yaitu sari buah nanas. Permasalahan yang dihadapi oleh petani nanas di Desa Bedali adalah keterbatasan alat yang dimiliki serta kurangnya pengetahuan dan ketrampilan dalam mengolah buah nanas. Permasalahan lain yang dihadapi yaitu apabila jumlah buah nanas melimpah, sedangkan permintaan pasar rendah, maka buah nanas tidak akan laku, akibatnya buah nanas menjadi busuk dan apabila sudah busuk maka akan dibuang. Hal ini akan menyebabkan kerugian bagi petani. Sehingga, ibu-ibu PKK yang juga menjadi petani buah nanas ini perlu mendapatkan perhatian untuk merubah mindset tidak hanya mampu bertani, tetapi juga mampu mengolah hasil pertanian. Metode yang dilaksanakan dalam kegiatan pengabdian masyarakat ini adalah memberikan pembinaan dan pelatihan dari aspek produksi dan aspek manajemen usaha. Dari program Pengabdian Masyarakat ini adalah pemberian pelatihan pengolahan buah nanas menjadi selai dan kue. Pelatihan pembukuan dan manajemen keuangan kepada ibu-ibu PKK dan pemberian peralatan mesin untuk menunjang produksi olahan minuman sari buah nanas.
\end{abstract}

Kata Kunci: Produk, Hasil Pertanian, Pengolahan. 


\section{Pendahuluan}

Aspek perekonomian merupakan aspek yang luas dari segala bidang usaha, baik usaha kecil, menengah, besar maupun lingkup rumah tangga dan masyarakat. Apabila kita membahas masalah ekonomi pasti tidak bisa terlepas dari aktivitas bisnis. Aktivitas bisnis bisa dilakukan oleh siapa saja baik individu maupun organisasi. Tujuan dari aktivitas bisnis adalah menghasilkan pendapatan untuk memenuhi kebutuhan hidup sehingga antara aktivitas bisnis dan pemenuhan kebutuhan hidup ada korelasi yang sangat kuat, namun tidak semua individu maupun organisasi dapat melaksanakan aktivitas bisnis, karena aktivitas bisnis memerlukan faktor produksi seperti modal, sumber daya manusia, skill, pengetahuan serta sarana dan prasaranan untuk usaha.

Kesejahteraan individu, rumah tangga maupun masyarakat bisa dilihat dari indikator pendapatan yang diperoleh, sehingga bagaimana caranya untuk mendapatkan pendapatan. Ada beberapa usaha yang dilakukan untuk mendapatkan pendapatan misalnya dari usaha jasa, dagang dan industri. Namun tidak semua pelaku bisnis bisa melaksanakan aktivitas usahaya dengan baik. Hal ini disebabkan karena terbatasnya kemampuan mereka dalam sistem manajemen, sistem produksi, sistem keuangan dan sistem akuntansi, sehingga apabila ada permasalahan yang berkaitan dengan keuangan, biasanya mereka mengalami kesulitan untuk menyelesaikan masalah, hal ini yang menyebabkan terhambatnya perkembangan usaha mereka.

Bagi perusahaan yang sudah besar pada umumnya sudah memiliki sistem manajemen yang baik, sehingga tingkat kesulitan dan kendala bisnis bisa diatasi, namun bagi masyarakat yang akan terjun sebagai wirausaha (enterpreneur) maka mereka harus mempersiapkan faktor produksi seperti: modal, sumber daya manusia, pengetahuan, skill, informasi, bahan baku yang akan diproses menjadi produk, sarana dan fasilitas, serta sistem manajemen yang baik sehingga aktivitas operasional perusahaan bisa berjalan lancar, mampu bersaing dan survive.

Bagi perusahaan yang baru berdiri dan akan berdiri, dengan keterbatasan modal yang kecil dan status kepemilikan masih perorangan, permasalahannya begitu komplek, diantaranya masalah modal, masalah manajemen, masalah produksi, masalah pemasaran, masalah sistem informasi akuntansi, dsb.

Masyarakat desa Bedali Kecamatan Ngancar Kabupaten Kediri, aktivitas utamanya sebagai petani yang mengolah hasil pertanian dan perkebunan. Sebagian besar mata pencaharian masyarakat Desa Bedali adalah sebagai petani. Desa Bedali merupakan desa yang berpotensi yaitu sebagai penghasil buah sirsak dan nanas disamping itu di kecamatan Ngancar terdapat tempat wisata Gunung Kelud , Kampung Indian dan Kampung Anggrek yang sudah cukup terkenal di Jawa Timuri.

Selama ini buah nanas tersebut belum bisa dimanfaatkan oleh masyarakat desa Bedali secara maksimal, mereka hanya menjual nanas kepada pedagang dengan harga yang murah yaitu Rp. 5.000,- per kg, padahal kalau dijual ke konsumen akhir bisa Rp. 10.000,- per kg. Seandainya diolah menjadi produk makanan dan minuman maka harganya bisa lebih tinggi, sehingga dapat membantu meningkatkan pendapatan masyarakat desa Bedali dan mencetak masyarakat desa menjadi wirausaha (enterpreneur).

Sampai saat ini masyarakat desa Bedali belum memanfaatkan buah nanas menjadi aneka produk makanan dan minuman secara maksimal. Rintisan kelompok ibu ibu PKK untuk membuat olahan sari buah nanas masih tergolong minim. Karena kelompok ibu ibu PKK di Desa Bedali ini masih memiliki peralatan yang terbatas dan belum mempunyai pengetahunan dan keterampilan dalam mengolah buah tersebut menjadi aneka produk makanan dan minuman yang 
bernilai tinggi. seperti keripik nanas, selai nanas, dan sirup nanas.

Selama ini hasil olahan ibu ibu PKK masih terbatas pada 1000 cup sari buah per bulannya. Apabila waktu panen raya, jumlah nanas sangat melimpah sehingga terjadi over produk, karena jumlah nanas melimpah maka harganya menjadi murah, Tidak ada pilihan lain bagi petani, karena dari pada laku dan dibuang maka disetujui saja harga yang sangat murah tersebut, padahal kalau dihitung petani mengalami kerugian.

Permasalahan lain apabila jumlah nanas melimpah, sedangkan permintaan nanas terbatas, maka buah tersebut tidak segera laku akibatnya menjadi busuk dan apabila sudah busuk maka akan dibuang sia-sia oleh masyarakat. Hal ini akan menyebabkan kerugian tentu bagi petani. Disamping itu masyarakat petani belum mempunyai pengetahuan akan manajemen marketing yang baik untuk menjual hasil pertanian nanas.

Sehingga kelompok ibu ibu PKK yang juga menjadi petani ini perlu mendapatkan perhatian untuk merubah pola pikir yaitu tidak hanya mampu bertani yang menghasilkan hasil pertanian tetapi juga harus mampu mengolah hasil pertanian. Untuk mengolah hasil pertanian diperlukan pengetahuan teknologi hasil pertanian. Sehingga kelompok tani di desa ini perlu mendapatkan perhatian pengetahuan tentang teknologi hasil pertanian. Pada umumnya mereka belum mengetahui dan memahami bagaimana mengolah hasil pertanian menjadi suatu produk yang mempunyai nilai jual yang lebih tinggi. Sehingga petani tidak hanya mampu menghasilkan hasil pertanian tetapi mereka juga mampu mengolah hasil pertanian, sehingga mereka mendapatkan keuntungan yang ganda yaitu sebagai petani dan sebagai wirausaha (enterpreneur) yang mengolah hasil pertanian.

Apabila mereka bisa mengolah buah nanas menjadi produk makanan dan minuman yang bernilai tinggi maka mereka akan mendapatkan keuntungan ganda yaitu: (1) mereka bisa menjual langsung buah nanas kepada pedagang, (2) mereka dapat memproduksi aneka produk makanan dan minuman dari bahan buah nanas, disamping itu untuk persediaan bahan nanas tidak perlu membeli kepada pihak lain, karena kelompok tani sudah mampu menghasilkan bahan nanas, sehingga untuk biaya bahan baku bisa lebih hemat dan tidak ada kekhawatiran akan sulitnya memperoleh buah nanas. Keuntungan lain adalah tidak ada buah nanas yang dibuang sia-sia karena bisa diolah mnejadi aneka produk makanan dan minuman.

Diharapkan dengan adanya pembinaan, pelatihan dan pengetahuan wirausaha terhadap kelompok tani desa Bedali dalam membuat aneka produk makanan dan minuman dari bahan nanas dapat menambah dan meningkatkan pendapatan masyarkat desa Bedali dan mengenalkan pada daerah lain bahwa di Kabupaten Kediri khususnya desa Bedali sudah dapat memproduksi aneka produk makanan dan minuman dari buah nanas. Selama ini yang kita kenal bahwa produk makanan dan minuman dari buah sebagian besar dari daerah Batu Malang.

Dengan demikian maka Kabupaten

Kediri akan menghasilkan aneka produk makanan dan minuman dari buah nanas, hal ini akan menambah khasanah potensi dari Kabupaten Kediri disamping sebagai daerah Wisata Gunung Kelud, Kampung Anggrek dan Kampung Indian,

Keberadaan Bumdes di Desa Bedali

Kecamatan Ngancar ini memberikan kontribusi yang cukup besar dalam membantu pendapatan desa setempat, utamanya memberikan pendapatan/ penghasilan kepada masyarakat sekitar. Masyarakat di desa Bedali kecamatan Ngancar Kabupaten Kediri sebagian besar mata pencaharian sebagai petani, namun ada PNS, guru, dan buruh dan bahkan ada yang tidak punyak pekerjaan.

Dari aktivitas di desa Bedali kecamatan Ngancar Kabupaten Kediri dapat diidentifikasi beberapa permasalahan: 
1. Masyarakat petani nanas hanya mampu menjual buah tersebut kepada pedagang,

2. Ketidakmampuan petani dalam mengolah hasil pertanian nanas menjadi produk yang bernilai jual tinggi.

3. Kelompok ibu ibu kelompok PKK Desa Bedali belum maksimal menggunakan teknologi tepat guna untuk mengolah produk hasil pertanian buah nanas.

4. Sebagian besar masyarakat Desa Bedali masih mempunyai pemikiran yang simple yaitu lebih baik menjual buah nanas walaupun dengan harga murah, dari pada mereka harus berpikir mengolah produk. Sehingga tidak ada inovasi dan kreatifitas dari kelompok tani untuk

5. Masyarakat kelompok ibu ibu PKK belum mempunyai alat yang memadai untuk mengolah buah nanas manjadi produk makanan dan minuman yang bernilai jual.

6. Kurangnya sarana dan prasarana untuk pengembangan usaha, seperti alat untuk menggoreng, alat pengaduk dodol, alat perajang buah, alat pengemas, alat peniris, uji kelayakan hasil produksi.

7. Masih terbatasnya wilayah pemasaran, yaitu hanya sekitar kabupaten Kediri saja. Hal ini disebabkan karena mereka tidak mempunyai link jaringan distribusi pemasaran produk yang luas, sehingga untuk melempar barang mengalami kesulitan.

8. Mereka dalam memasarkan olahan buah nanas tidak mempunyai pengetahuan dan keahlian di bidang pemasaran, pokoknya hanya jual dari pada buah busuk, sehingga target dan volume penjualan lambat. Apabila hasil penjualan lambat maka buah akhirnya menjadi busuk dan dibuang

9. Kurangnya pengetahuan tentang sistem akuntansi, sehingga dari transaksi penjualan tidak pernah dibukukan. Sehingga mereka tidak mengtahui dengan pasti berapa biaya yang dikeluarkan dan berapa hasil yang diterima. Mereka hanya menghitung penerimaan uang saja, bahkan ada yang oleh pedagang dihutang.

10.Perolehan modal dari pinjaman bank yang bunganya relatif cukup tinggi. Dan mereka umumnya takut mengambil pinjaman bank karena dikawatirkan tidak bisa membayar. Hal ini yang menyebabkan terhambatnya untuk memulai usaha.

\section{Pelaksanaan Dan Metode}

Pelaksanaan Program Kemitraan Masyarakat ini dilaksanakan di Desa Bedali, Kecamatan Ngancar, Kabupaten Kediri. Kegiatan ini dilaksanakan pada bulan Maret sampai dengan Agustus 2019. Kegiatan pengabdian masyarakat ini dimulai dengan identifikasi masalah yang ada di kelompok petani nanas, dari hasil identifikasi tersebut memberikan hasil kesepakatan kerja sama kelompok ibu ibu PKK Desa Bedali kecamatan Ngancar Kabupaten Kediri dengan tim Pengabdian masyarakat Universitas Islam Kadiri untuk melakukan pelatihan dan pembinaan untuk mencetak kelompok ibu ibu PKK Desa Bedali untuk menjadi wirausaha (enterpreneur).

Pelatihan dan pembinaan yang dilakukan adalah penyusunan anggaran induk, membuat layout produksi, pembinaan manajemen (manajemen produksi, manajemen keuangan, manajemen pemasaran) dan sistem akuntansi sampai dengan membuat laporan keuangan, menganalis laporan keuangan serta bagaimana mengambil keputusan dengan tepat dan akurat. Membuat aneka produk makanan dan minuman dari bahan buah nanas, antara lain selai nanas dari hasil limbah ampas sari buah nanas. Teknologi tepat guna yang diberikan yaitu alat penunjang pembuatan sari buah nanas yaitu cup sealer otomatis. Serta peralatan penunjang lainnya untuk membuat olahan sari buah nanas dan selai.

\section{Hasil dan Pembahasan}

Kegiatan ini diawali dengan koordinasi awal antar tim tentang program pengabdian masyarakat di Desa Bedali. 
Kemudian tahapan selanjutnya adalah persiapan dan koordinasi dengan ibu-ibu PKK Desa Bedali. Kegiatan ini untuk memberikan sosialisasi tentang kegiatan pengabdian masyarakat dan untuk mengkoordinasikan jadwal kegiatan serta program-program yang akan dilakukan selanjutnya.

Persiapan kegiatan pengabdian masyarakat ini meliputi perijinan kepada pemerintah setempat, hasil yang didapat sangat bagus dengan adanya kegiatan ini mendapatkan dukungan dari kepada desa Bedali dan Bumdes desa Bedali. Selanjutnya, kegiatan pelatiahan-pelatihan, antara lain:

1. Pelatihan produk, yaitu memberikan pelatihan pengolahan limbah ampas sari buah nanas menjadi selai nanas.

2. Pelatihan pembuatan kue nastar dengan isian selai nanas

3. Pelatihan pengemasan sari buah nanas.

4. Pelatihan penyusunan anggaran induk, membuat layout produksi,

5. Pembinaan manajemen, meliputi manajemen produksi, manajemen keuangan.

6. Pelatihan manajemen pemasaran

7. Pelatihan sistem akuntansi

8. Pelatihan membuat laporan keuangan, menganalis laporan keuangan serta bagaimana mengambil keputusan dengan tepat dan akurat.

Kegiatan pengabdian masyarakat desa Bedali diharapakan mampu mengangkat perekonomian petani dan terutama ibu-ibu PKK yang merupakan mitra kegiatan pengabdian masyarakat ini. Hasil yang produk olahan sari buah nanas diharapkan bisa diajukan legali-tasnya sehingga dapat bersaing dengan brand yang sudah ada dipasaran. Hasil pengolahan limbah sari buah nanas berupa ampas nanas dapat digunakan sebagai selai nanas. Pelatihan pengo-lahan selai nanas sangat membantu mengatasi ketersediaan limbah nanas dan dapat membantu memberikan tambahan income seelain dari sari buah nanas. Hasil pengolahan produk lainnya adalah pelatihan pembuatan kue nastar, isian nastar yang digunakan adalah selai nanas yang diolah tersebut. Diversifikasi produk ini diharapakan dapat menjadi alternative dalam mengangkat status perekonomian warga desa Bedali khususnya petani nanas dan ibu-ibu PKK setempat.

Pelaksanaan pengabdian masyarakat selanjutnya adalah memberikan pelatihan tentang pengemasan produk, hasil produk yang telah dibuat perlu dilakukan pengema-san agar lebih menarik dan lebih higienis sehingga mampu memberikan nilai jual yang bagus. Pelatihan ini berupa pelathan membuat desain kemasan minuman sari buah nanas, yaitu peberian label kemasan, merk dagang, pengemasan sari buah nanas menggunakan cup sealer semi otomatis sehingga memudahkan dalam mengemas sari buah nanas, karena selama ini masih menggunakan pengemasan yang manual dan tidak berlabel. Selain kemasan minuman sari buah nanas, juga dilakukan pemberian pelatihan pengemasan selai nanas, dan kue nastar. Pelatihan pengemasan ini juga untuk menguji daya simpan dari produk yang ada, sebagai referensi untuk pengajuan legalitas produk selanjutnya.

Pelatihan penyusunan anggaran induk, yaitu perhitungan modal yang dimiliki oleh mitra, perbaikan manajemen, membuat job discription dengan jelas. Kemudian, menentukan produk satuan yang akan diproduksi termasuk desain produk supaya menarik minat konsumen dan produk diminati konsumen. Menghitung biaya produksi, bahan yang dipakai, biaya tenaga kerja dan biaya overhead pabrik dan biaya lain-lain.

Membuat layout produk dan desain produk, menentukan jadwal produksi, menentukan kebutuhan bahan produksi, menentukan sarana dan prasarana produksi, melakukan penugaasan produksi supaya produk yang dihasilkan berkualitas baik.

Membuat Laporan Harga Pokok Produksi (berapa biaya produksi sesungguhnya yang dikeluarkan untuk menghasilkan suatu produk). Menghitung biaya produksi, menghitung harga pokok penjualan dan menentukan harga jual. 
Menentukan wilayah daerah pemasaran dan strategi pemasaran

Melakukan promosi dan pengenalan produk, mentraining tenaga penjual, mengawasi produk di pasaran dan selanjutnya membuat laporan keuangan meliputi membuat laporan laba/rugi, membuat laporan neraca, menganalisis laporan keuangan. Melakukan kegiatan pendampingan, monitoring dan evaluasi untuk keberhasilan dan berkelanjutan program.

Kegiatan Program Kemitraan Masyarakat dilaksanakan secara bertahap, Kegiatan tahap pertama antara lain penyerahan alat dan bahan kepada kelompok PKK, selanjutnya pelatihan pengolahan selai dan pembuatan layout produksi, pelatihan pembukuan, dan tahap akhir adalah pendampingan dan evaluasi kegiatan. Hasil Kegiatan tersebut antara lain:

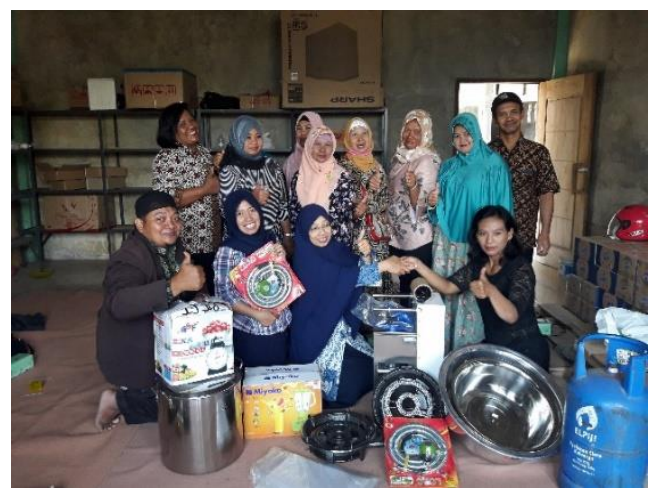

Gambar 1. Penyerahan alat dan bahanbahan kepada Kelompok PKK Desa Bedali

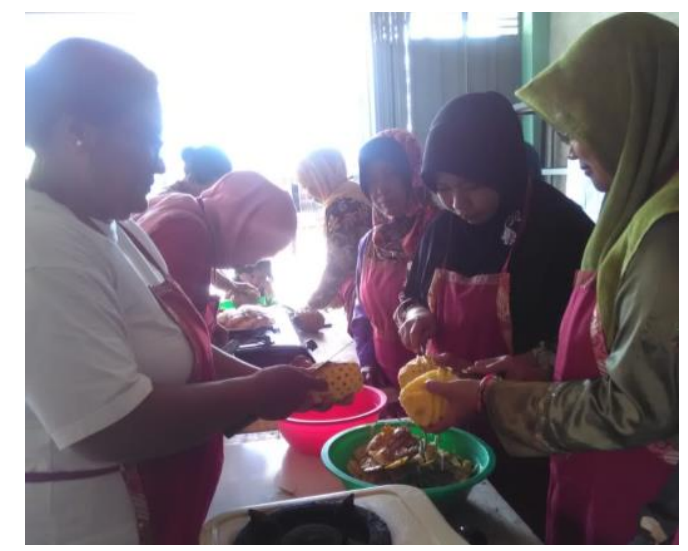

Gambar 2. Proses Pengupasan nanas

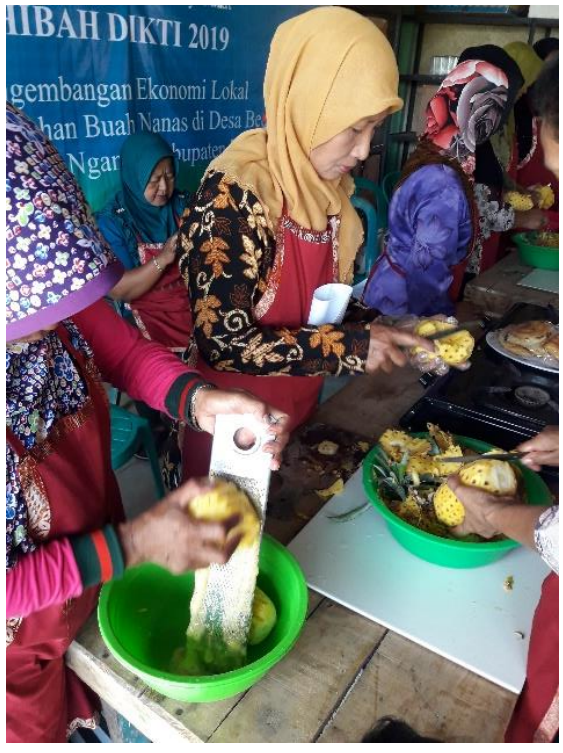

Gambar 3. Proses Pemarutan nanas

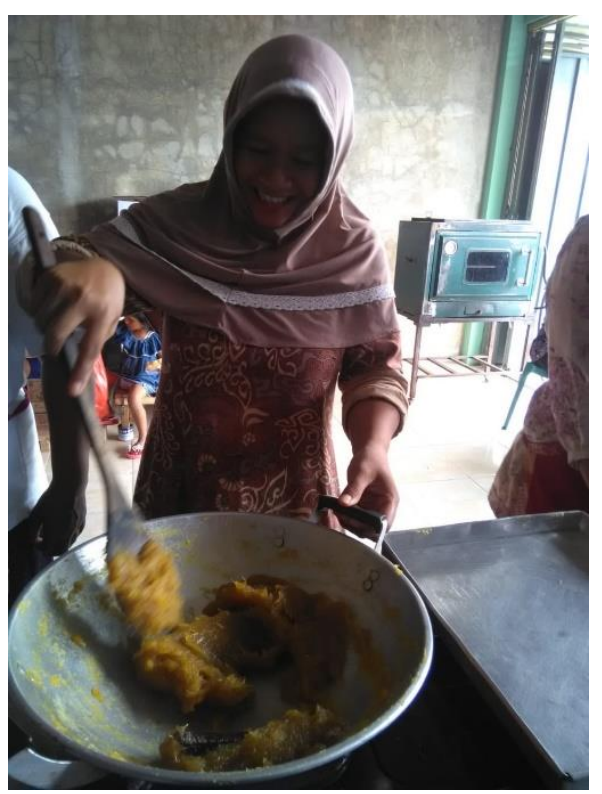

Gambar 4. Pelatihan pembuatan selai nanas

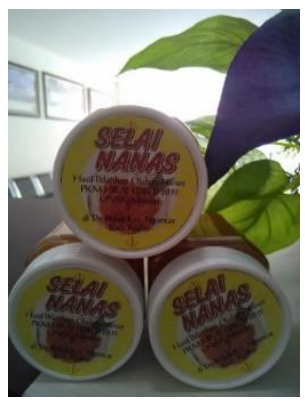

Gambar 5. Produk selai sari buah nanas 


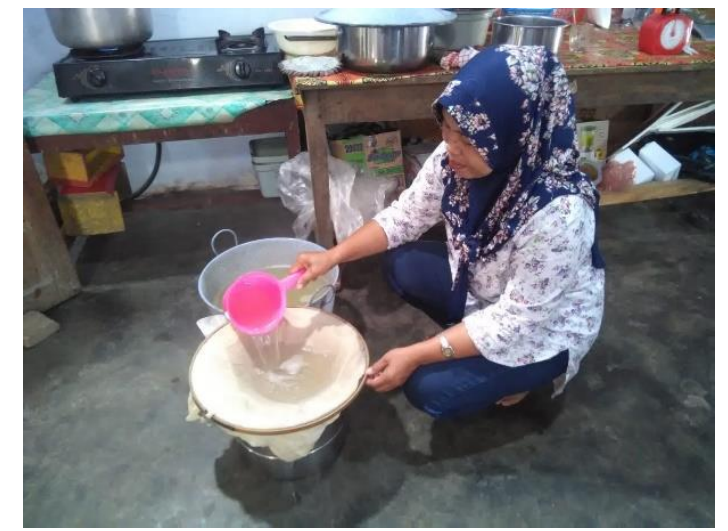

Gambar 5. Penyaringan sari buah nanas

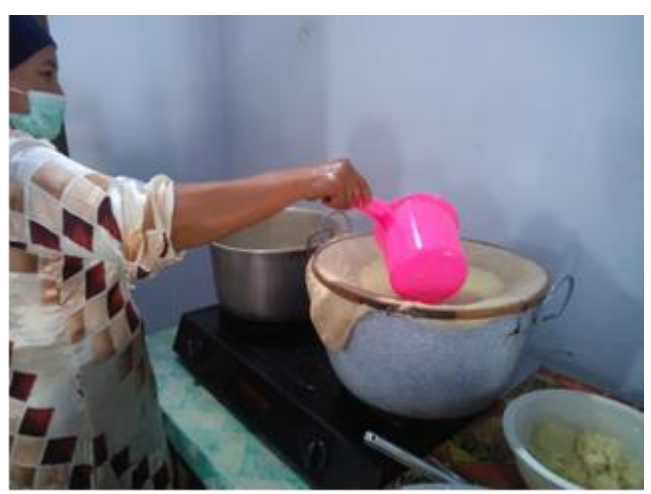

Gambar 6. Perebusan sari buah nanas

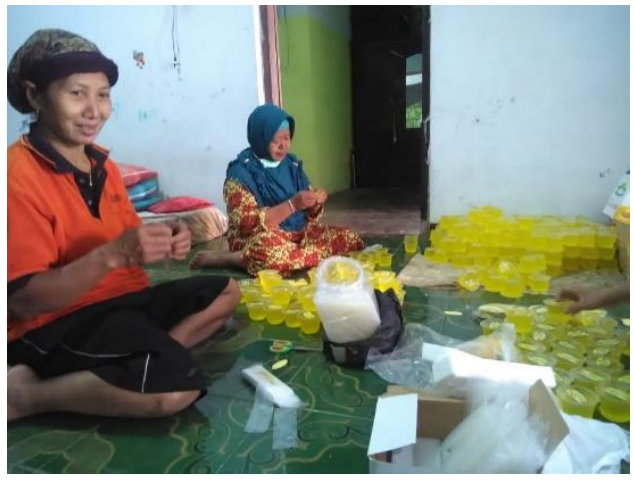

Gambar 7. Pengemasan minuman sari buah nanas

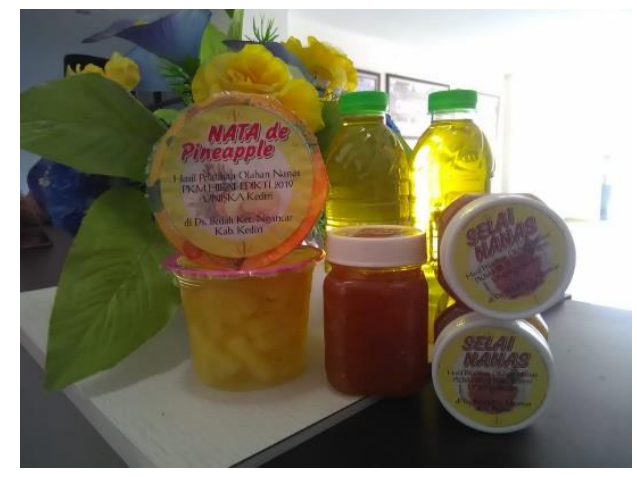

Gambar 8. Produk minuman sari buah nanas

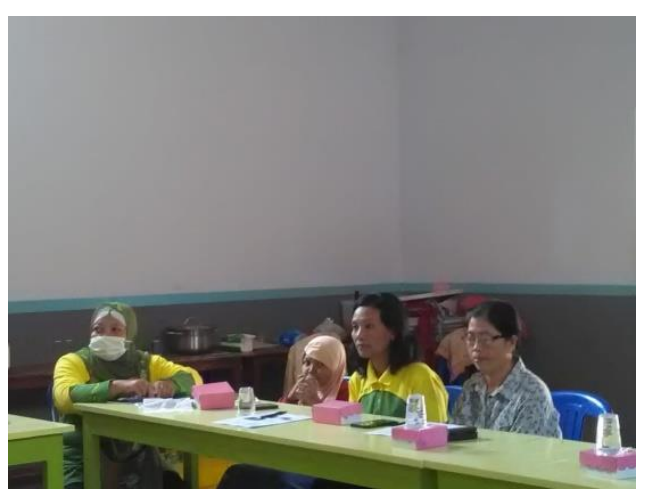

Gambar 10. Pelatihan Manajemen Pemasaran

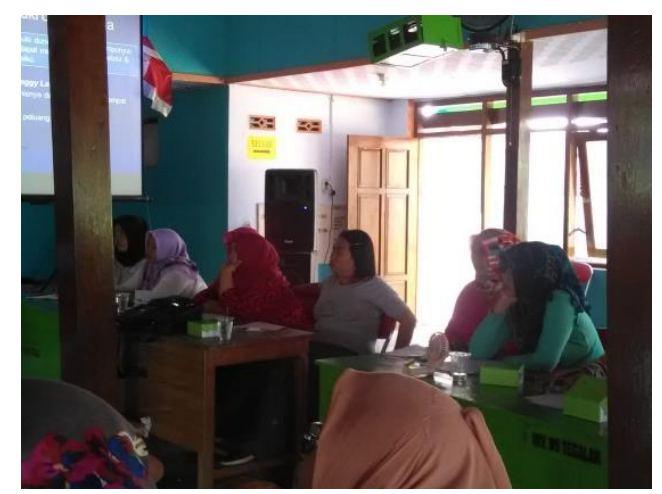

Gambar 11. Pelatihan Akuntansi Keuangan 


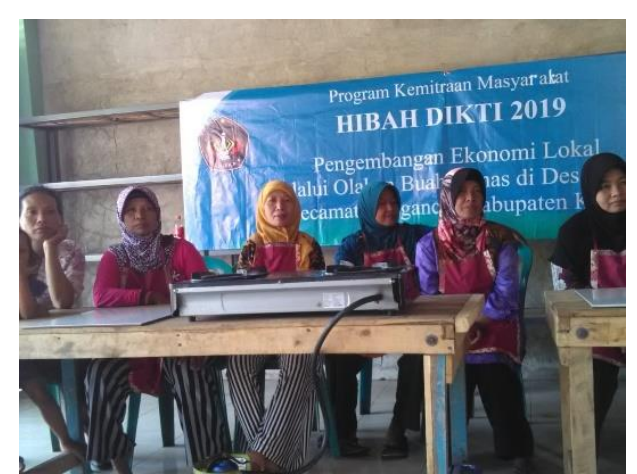

Gambar 12. Pelatihan pembuatan laporan keuangan

\section{Penutup}

\section{Kesimpulan}

Melalui serangkaian kegiatan pengabdian masyarakat ini terdapat peningkatan produksi sari buah nanas oleh ibu-ibu PKK Desa Bedali. Sebelum adanya kegiatan ini sari buah yang mampu diproduksi sebanyak 1.000 cup per bulan, setelah adanya kegiatan pengabdian masyarakat ini meningkat menjadi 2.000 cup per bulan. Produk yang dihasilkan juga lebih bervariasi dengan adanya produk tambahan berupa selai nanas dan kue.

Tenaga kerja yang terlibat dalam pembuatan sari buah nanas juga bertambah dari 10 orang menjadi 20 orang setelah kegiatan pengabdian masyarakat ini.

\section{Saran}

Berdasarkan hasil kegiatan pelatihan, pendampingan di Desa Bedali Kecamatan Ngancar ini dapat disarankan:

1. Pendampingan pemasaran sari buah nanas melalui dinas koperasi dan UMKM wilayah setempat.

2. Perancangan dan pendampingan untuk pembuatan rumah produksi sari buah nanas.

\section{Ucapan Terima Kasih}

Terima kasih kami sampaikan kepada Kemenristek DIKTI dan seluruh civitas Universitas Islam Kadiri dalam mendukung kegiatan Program Kemitraan
Masyarakat di Desa Bedali kecamatan Ngancar, Kabupaten Kediri.

\section{Daftar Pustaka}

Best, Roger, J.2004. Market-Best Management: Strategies For Growing Customer Value And Profitability. 3nd Edition. PrencticeHall inc. New Jersey

Burggraff Willem. Et. Al. The Enterpreneur and The Enterpreneurship cycle, 2008, Assen,: Royal Van Gorcum

Craveb W Davidm and Nigel F Piercy, 2007 Stategic Marketing, 8nd Edition Irwin, Mc Graw Hill.

Corsi, Patrick, et, al, Innovation Enginering, 2006, London : iste

Day, George S, 1999 Market Driven Strategy: Process For Creating Value. New York The Free Press A Division of Simon \& Schuster Inc, New York.

Djuamdi, Anton, Membangun Karakter Wirausaha dan Praktik Bisnis di Bidang Pangan, 2010, Grasindo, Jakarta

Fandy Tjiptono, Gregorius Chandra, 2008 Dadi Andriana, Pemasaran Strategik, Jakarta: CV Andi Offset

Fuad, M, Christine H, Nurlela, Sugiarto, Pengantar Bisnis, 2000, PT. Gramedia, Jakarta

Harmaizar, Menggali Potensi Wirausaha, 2006, CV. Dian Anugrah Perkasa

http://irmadevita.com/2007/ Prosedur Cara dan Syaray Pendirian CV

Indrajaya, Richi, Jangan Takut Mulai Bisnis. 2008, Puspa Swara, Jakarta

Indrajid, Dr, Richardus Eko, ProsesBisnis Outsourcing, 2004, Grasindo, Jakarta

Kartajaya, hermawan. Siasat Bisnis, Gramedia, 2004, Jakarta

Kotler, Philip, Marketing Management, 2006, Elevent h Edition, New Jersey

Malahayati, S.Psi, Rahasia Bisnis Rosululloh, 2010, Jogya Great Publisir, Jogyakarta

Manurung, Dr, Laurensius, Jiko Warsito. Strategi Dan Inovasi Bisnis, 
meningkatkan Kinerja Usaha. 2010, Elex Komputindo, Jakarta

Michael Hammer and James Champy, Reenginering the Corporation: A Manifesto for Business Revolution, 1993, Harper Busioness.

Nugroho, A, Suharyadi, Purwanto, Kewirausahaan, Membangun Usaha Sukses Sejak Usia Muda, 2007, PT, Salemba Empat, Jakarta.

Paeru, Rdi H, Juwita Ratnasari, Kuliah Kalau Bisnis Lancar, 2007, Penebar Plus, Jakarta

Rangkuti, Freddy, Analisis SWOT, 2006, Teknik Membedah Kasus, 2006, PT, Gramedia, Jakarta.

Salim, Joko, Step By Step Bisnis On Line, 2009, Elex Media Komputindo, Jakarta

Sari, Elsi Kartika, et, al, Hukum Dalam ekonomi, , 2007, Bandung: Grasindo

Shet, N, Jagdish, Tujuh Tanda Kehancuran, Bisnis Sukses, 2007. PT. Gramedia, Jakarta

Sitio, Arifin dan Tamba, Koperasi: Teori dan Praktik, 2001, Erlangga, Jakarta

Sutomo, Djati, Menjadi Enterpreneur Jempolan, Repubilka, Jakarta

Susanto, Happy. Proposal Tepat Bisnis Melesat, Kiat Jitu Menggolkan Proposal, 2009, Visimelia Pustaka

Sutanto, M, Sebelas Rahasia Memuali Bisnis Tanpa Uang, Belajar Dan Kesuksesan Pengusaha Top Dunia, 2005, CV. Andi Offset, Yogyakarta

Syarif, Reza M, Smart Business, Mengarah Ketajaman Naluri Bisnis, 2008, Naluri Bisnis, Gema Insani

Widjayanto, Biye, Cara Aman Memulai Bisnis, 2009, Grasindo , Jakarta

Zaharuddin, Ir, Harmaizar, Menggali Potensi Wirausaha, 2006, CV. Dian Anugerah Prakoso, Bekasi. 